Asian J. Med. Biol. Res. 2020, 6 (3), 449-459; doi: 10.3329/ajmbr.v6i3.49793

\author{
Asian Journal of \\ Medical and Biological Research \\ ISSN 2411-4472 (Print) 2412-5571 (Online) \\ www.ebupress.com/journal/ajmbr
}

Article

\title{
Spawning and developmental biology of endangered Pabdah catfish, Ompok pabda (Hamilton, 1822)
}

\author{
Israt Jahan Tumpa, Md. Saddam Hossain, Md. Nagim Uddin and Zakir Hossain* \\ Department of Fisheries Biology and Genetics, Bangladesh Agricultural University, Mymensingh-2202, \\ Bangladesh
}

*Corresponding author: Professor Dr. Zakir Hossain, Department of Fisheries Biology and Genetics, Bangladesh Agricultural University, Mymensingh-2202, Bangladesh. Phone: +8801724-939693; Fax: +8809161510; E-mail: zakir.fbg@bau.edu.bd

Received: 11 August 2020/Accepted: 16 September 2020/ Published: 30 September 2020

\begin{abstract}
Pabdah catfish, Ompok pabda was collected from the Old Brahmaputra river and successfully induced to breed by injecting pituitary gland extract to evaluate spawning performances and developmental stages under a photo microscope from February 2018 to August 2018. In this study, absolute fecundity of the $O$. pabda females varied from 6,676 to 20,410 eggs per fish. The GSI value of male and female was lower during September and gradually attained its maximum level in June with the highest average value $6.75 \pm 0.2$ and $1.053 \pm 0.2$ in female and male, respectively. The average fertilization and hatching rate of eggs were found $78.67 \pm 1.33 \%$ and $70.21 \pm 0.73 \%$, respectively at $24.5 \pm 1.0^{\circ} \mathrm{C}$. Fertilized eggs were brownish in color, very transparent and adhesive in nature with 1.0 to $1.2 \mathrm{~mm}$ in diameter. Cleavage stages were completed at $1.50 \mathrm{~h}$ of post fertilization and it eventually took $23.00 \mathrm{~h}$ for hatching. Larva was appeared with prominent three pairs of barbells after $12.00 \mathrm{~h}$ of hatching. It took $3 \mathrm{~d}$ post hatching to absorb their yolk sac and feeding exogenously. The present work supplemented to the deficient information on detailed spawning and developmental biology of O. pabda in order to save this species from extinction.
\end{abstract}

Keywords: Ompok pabda; spawning; embryonic development; larval development

\section{Introduction}

Pabdah catfish, Ompok pabda is a freshwater catfish out of 158 inland species (Rajagopal and Davidar, 2013) belonging to the family Siluridae of the order Siluriformes. O. pabda dwells and breeds in the rivers and reservoirs (Mukherjee et al., 2002). It has a wide geographical range in India, Bangladesh, Nepal, Sri Lanka, Afghanistan, Pakistan, China, Thailand and Myanmar (Mukhopadhyay and Ghosh, 2007) and can thrive in all types of freshwater habitats, especially in rivers, canals, beels, swamps, floodplains and ponds. This fish species has high preference as a table fish to the people of Bangladesh, East India and North India as well (Jhingran, 2004) due to its delicious taste and high nutritional value with good amount of lipoprotein, protein and mineral content in its flesh (Banik et al., 2012). Recently, it has made its entry in the international ornamental fish market and has high acceptability among the fish hobbyists (Gupta and Banerjee, 2013; Gupta, 2018). Due to high market value and consumer demand $O$. pabda bears exceptional criteria in aquaculture but the biggest constraint is lack of adequate supply of stockable fry. At present, this fish species is facing high risk of extinction in nature (Hossen et al., 2015) as over the last 10 years its wild population has undergone a steady decline $(>50 \%)$ due to loss of its population which attributes degradation of breeding and feeding ground, pollution, over-exploitation, poor nutrition, extensive use of pesticides and insecticides in agricultural fields along with non-judicious land use pattern and most importantly poor breeding and rearing management (Chakrabarty et al., 2006; Purkayastha et al., 2012). Poor domestication of $O$. pabda in culture system due to insufficient knowledge on breeding and farming technique is also a reason behind this declination (Chakrabarty et al., 2006). Due to reduced abundance in nature, it has already been enlisted as an endangered species both in India (CAMP, 1998) and Bangladesh (IUCN, 2015). The detailed knowledge about spawning and 
developmental biology could be the first priority that will restrict the declination of $O$. pabda. Moreover, to ensure the availability of fry as well as to prevent this fish species from extinction it is important to establish a dependable induced breeding and larvae rearing technique. Although some workers (Banik et al., 2012; Sarma et al., 2012) had previously reported successful induced breeding of pabda, but this had not been standardized to be recommended at farmer's level for commercial seed production. Embryonic development and larval development which provides remarkable information in itself that are imperative and consequential to the successful rearing of larvae for large scale seed production (Marimuthu and Haniffa, 2007). Optimization of mass seed production and rearing management much rely on early life history information which is very much important to optimize larval growth and survival. Earlier few studies have been carried out on food, feeding habit and reproductive biology of $O$. pabda; but consolidated report on these aspects so far is not available. The developmental biology of $O$. pabda is an indispensable aspect which may be considered as base line information for the researchers and fish culturists, who are engaged in the seed production of the species (Chakrabarti et al., 2008). Therefore, the present study has been conducted to provide detailed information about onset of spawning, the early embryonic and larval development of $O$. pabda.

\section{Materials and Methods}

\subsection{Experimental site and brood fish collection}

O. pabda $(\mathrm{N}=60)$ weighing average length $21.74 \pm 0.71 \mathrm{~cm}$ and weight $56.45 \pm 1.97 \mathrm{~g}$, respectively were collected (February, 2018) from the sampling sites located in Mymensingh region of the Old Brahmaputra river, Bangladesh lying at $24^{\circ} 2^{\prime \prime} 0^{\prime}$ North latitude and $90^{\circ} 59^{\prime \prime} 0^{\prime}$ East longitude. After collection, the fishes were transported to Mini Hatchery and Laboratory Complex, Faculty of Fisheries, Bangladesh Agricultural University in oxygenated polythene bags. Upon arrival, fish were sexed and conditioned for about 15 days. The fishes were stocked in cisterns having $1.22 \mathrm{~m} \times 2.44 \mathrm{~m} \times 0.46 \mathrm{~m}$ dimension with $30 \mathrm{~cm}$ water depth and fed with pellet diet having $30 \%$ crude protein at $5 \%$ body weight per day for rearing up to their maturation.

\subsection{Physicochemical condition of water}

Fresh and well aerated water was used for domestication of the fish in all the cisterns. Physicochemical parameters of water in all cisterns were recorded periodically for rearing and breeding this fish species. Temperature, $\mathrm{DO}$ and $\mathrm{pH}$, total alkalinity and total hardness were determined by using a Celsius thermometer, digital DO meter (multi 340 iset, DO-5509; China), portable digital pH meter (MICRO-TEMP, pH 500, Romania), HI3811 Alkalinity test kit and HI3812 Hardness test kit of HANNA, respectively.

\subsection{Induced breeding, fertilization and incubation of fertilized eggs}

The breeding of $O$. pabda brood was conducted in June, 2018. Good looking, healthy and sexually matured broods were selected for breeding. Mature male and female broods (2:1) were selected on the basis of secondary sexual characteristics. The mature males were identified by their flat abdomens and long protruded genital papillae. On the other hand, the females could easily be recognized by their soft swollen abdomen and round swollen urogenital papillae. Broods were collected by reducing the water of the cistern and the selected broods were kept in fiber glass tank with heavy shower for about $6 \mathrm{~h}$ for conditioning prior to injection with pituitary gland (PG extract) collected from M/s. M V Enterprise, Jashore, Bangladesh. Male and female fish were kept in separate tanks and constant water flow was maintained to ensure proper aeration. The females $(80-100 \mathrm{~g})$ were induced with an injection of $3 \mathrm{mg} \mathrm{PG} / \mathrm{kg}$ body weight and the males $(60-70 \mathrm{~g})$ were induced with an injection of $6 \mathrm{mg} \mathrm{PG} / \mathrm{kg}$ body weight as $1^{\text {st }}$ dose. After $6 \mathrm{~h}, 2^{\text {nd }}$ dose of PG were given at $16 \mathrm{mg}$ PG/kg body weight of females and 6-8 mg PG/kg body weight of males. Doses using a $1 \mathrm{ml}$ graduated syringe were injected intramuscularly at an angle of $45^{\circ}$ at base of the pectoral fin. Eggs were collected from the injected female through gentle pressure on the abdomen and milt was collected by dissecting the injected male. Sperm suspension was prepared after thoroughly maceration of testes with $0.9 \%$ saline solution. Eggs and milt were gently mixed with the help of a feather for fertilization. Fertilized eggs were collected, transferred and spread as homogeneously as possible on hatching trays $\left(101.6 \times 40.6 \times 12.7 \mathrm{~cm}^{3}\right)$. Fertilized eggs in trays received gentle shower and dead eggs and eggs shells were removed from the incubator by siphoning within one hour of hatching to protect the hatchlings from fungal infection. The hatchlings were left in the incubator few days for post-hatching observation. The water was replaced every day to maintain good water quality and was agitated to prevent the overlapping or clumping of eggs on the bottom. Although the hatchlings of $O$. pabda get nutrition from the yolk sac up to $3 \mathrm{~d}$ of hatching, the larvae started first feeding from $36-72 \mathrm{~h}$ post-hatching at ambient temperature of $26-28^{\circ} \mathrm{C}$. Hard-boiled chicken egg yolk was provided as first feed for the hatchlings up to satiation level. 


\subsection{Sampling of eggs and larvae}

The fertilized egg samples were randomly collected from the hatching trays with the help of a dropper and were taken in a petridish containing water for studying the developmental stages of $O$. pabda at every 10-15 min interval until hatching and every $30 \mathrm{~min}$ and $1 \mathrm{~h}$ interval till completion of larval developmental stages. Microscopic observation was continued till first feeding of fry. At least 8-10 sample eggs and larva undergoing developmental process were observed to obtain precise information about developmental stages.

\subsection{Image capture and analysis}

Embryonic and larval developmental stages of $O$. pabda were photographed (40x) under a binocular microscope OLYMPUS CX41RF, Tokyo, Japan with a digital camera (Pixel 5.0) OLYMPUS DP22 Tokyo, Japan.

\subsection{Growth and somite indices}

The weight of each fish was taken with a 3 digit sensitive electric balance (AND-GULF, Model-EK600, UAE). For the estimation of gonado-somatic index, 6 fish from each cistern were taken at every month till spent period. Gonado-somatic index was expressed according to Devlaming et al. (1982) method for assessing the development of gonads and calculated as, GSI $=($ gonad weight/body weight $) \times 100$.

Fecundity was determined by following the method of Hartman and Conkle (1960) using formula, $\mathrm{F}=\mathrm{nG} / \mathrm{g}$ where, $\mathrm{F}$ is the fecundity; $\mathrm{n}$ is mean number of eggs in all samples; $\mathrm{G}$ is the weight of ovary and $\mathrm{g}$ is the weight of samples (eggs were collected from anterior, middle and posterior portion of entire ovaries).

For calculation of fertilization and hatching rates, a portion of fertilized eggs were taken and incubated on sieve. Fertilized eggs were counted on the basis of their colour and transparency. After completion of hatching, the number of newly hatched larvae of each sieve was counted. Fertilization and hatching rates were recorded as spawning indices using the formula:

$\%$ Fertilization $=($ No. of fertilized eggs/No. of total eggs $) \times 100$

$\%$ Hatching $=($ No. of hatched eggs/No. of total fertilized eggs $) \times 100$, respectively .

\subsection{Statistical analysis}

Correlation analysis amongst body weight, fecundity and gonad weight and between male GSI and female GSI were calculated by MS Excel 2017. Significance level was evaluated using SPSS version 22.0.

\section{Results and Discussion}

\subsection{Physicochemical parameters of water}

Water quality parameters are the most important factors which influence the growth, reproduction and other biological activities of fish. During the entire experimental period, temperature, $\mathrm{pH}$ and DO were around $26.5 \pm 2^{\circ} \mathrm{C}, 7.4 \pm 0.2$ and $6.7 \pm 0.5 \mathrm{mg} / \mathrm{L}$, respectively (Table 1). Similar water quality parameters were found for the suitable health condition and survival rate of different species of fish and other aquatic organisms (Jahan $e t$ al., 2020; Mollah and Hossain, 1995; Mollah and Hossain, 1998; Mollah and Sarowar, 2009; Islam et al., 2018; Hossain et al., 2018). Alkalinity and hardness was maintained $85 \pm 7 \mathrm{mg} / \mathrm{L}$ and $56 \pm 8.3 \mathrm{mg} / \mathrm{L}$, respectively for broodstock management. Sarma et al. (2012) found similar result for incubation and nursery rearing unit of $O$. pabo.

\subsection{Breeding periodicity, fecundity and spawning performances of $O$. pabda}

The experimental fish, $O$. pabda was found to breed in the month of June to August with spawning peak in June. Akhteruzzaman et al. (1993) have also documented May to August while Chakrabarty and Chakrabarti (2005) have reported early June to late July as the breeding season in West Bengal. Similarly Saha et al. (2014) have documented early May to early June for Heteropneustes fossilis. In this study, absolute fecundity of the $O$. pabda varied from 6,676 eggs (with total length of $19.9 \mathrm{~cm}$ and total body weight of $47.65 \mathrm{~g}$ ) to 20,410 eggs (with total length of $25.4 \mathrm{~cm}$ and total body weight of $82.5 \mathrm{~g}$ ). The average fecundity was $11091 \pm 1876$ eggs per fish and was higher during early May to late July which sharply decreased during late August to October. Banik et al. (2012) have reported the range of 2,190 to 41,552 eggs for $O$. pabda while Malla and Banik (2015) have documented the absolute fecundity ranged from 2,190 to 41,552 eggs per fish for another species of pabda. The fertilization and hatching rate of eggs are important indicators of good reproductive performance. In this study, fertilization and hatching rate of eggs were found $78.67 \pm 1.33 \%$ and $70.21 \pm 0.73 \%$, respectively at $24.5 \pm 1.0^{\circ} \mathrm{C}$ temperatures. More or less similar fertilization and hatching rate was found in different fish species (Raizada $e t$ al., 2013; Hossen et al., 2014c). 


\subsection{Gonado-somatic index and correlation between body weight, gonad weight and fecundity}

GSI gives a clear indication on the gonadal development and breeding season of a fish. During the study period, the GSI of female was relatively higher than that of males showing decreasing trend during September to March and its maximum level in June and July.. In case of female $O$. pabda, the highest GSI (\%) was found as $6.75 \pm 0.2$ in the month of June and the lowest was found as $2.19 \pm 0.3$ in March. However in male, very low GSI (\%), $0.145 \pm 0.02$ was observed in the month of September and very high GSI (\%) 1.053 \pm 0.2 in June (Table 2). Motin et al. (2013) have found the highest GSI (\%) 4.06 in September and 0.76 in December for female and male of $O$. pabo, respectively. Similar GSI (\%) has also been reported in Colisa fasciatus and Nandus nandus (Hossen et al., 2014b; Reza et al., 2013). The values of correlation coefficient (r) were established between male GSI (\%) and female GSI (\%) and amongst the body weight and gonad weight and fecundity. It was found that all these relationships were positively correlated and showed a straight line relationship which is expressed by an equation, $\mathrm{Y}=\mathrm{a}+\mathrm{bX}$ where, the values of intercept (a), regression co-efficient (b) and correlation coefficient (r) and $\mathrm{X}$ and $\mathrm{Y}$ are the variables. All these correlation coefficient (r) showed significance at $\mathrm{p} \leq 0.01$. Gonad weight was nearly related to the body weight (Figure 1) and thus gonad weight was directly proportional to the fecundity (Figure 2). Behera (2012) was also found positive correlation co-efficient between weight of female fish and gonad weight at $\mathrm{p} \leq 0.05$ for an ornamental fighting fish, Betta splendens. In addition, male and female GSI also showed a positive correlation $(\mathrm{r}=0.951 ; \mathrm{p} \leq 0.01)$ considering the reproductive months (Figure 3). Similar significant positive correlation $(\mathrm{p}<0.05)$ was also observed for male and female GSI in Clarias gariepinus (Yusuf et al., 2013) and Anabas testudineus (Marimuthu et al., 2009).

\subsection{Early embryonic development of $O$.pabda}

The embryonic development and their respective time of observation and key features of $O$. pabda are presented in Table 3. The embryonic development started soon after fertilization of eggs by the motile sperm. The unfertilized eggs (Figure 4A) were blackish in colour, demarsal, spherical and not transparent in nature. The eggs were not adhesive and were enveloped by a thick blackish chorion and had a large yolk sphere in the centre of the chorion. The sizes of the unfertilized eggs were $0.90-1.0 \mathrm{~mm}$ in diameter. Hossen et al. (2014a) also found the unfertilized eggs of Trichogaster fasciataas floating, opaque, whitish and slightly elongated shaped with a range from 0.20 to $0.30 \mathrm{~mm}$ in diameter. Fertilized eggs of $O$. pabda were brownish in color and adhesive in nature and were very transparent and had a reddish brown spot on one side which is easily recognizable with naked eye. Light pinkish color and adhesive nature are similar to those of other catfish species such as Mystus cavasius (Rahaman et al., 2004), H. fossilis (Puvaneswari et al., 2009) and $O$. malabaricus (Vijayakumar, 2010). The sizes of the fertilized eggs of $O$. pabda were 1.0 to $1.2 \mathrm{~mm}$ in diameter (Figure 4B). Zadmajid et al. (2018) studied the embryonic and larval development in wild-caught Levantine scraper, Capoeta damascina and the fertilized eggs were $3.22 \pm 0.03 \mathrm{~mm}$ in diameter. Puvaneswari et al. (2009) showed that the fertilized eggs of $H$. fossilis were demersal, non-adhesive, spherical, brownish green in color and the average diameter of the fertilized eggs ranged from 1.30 to $1.50 \mathrm{~mm}$. Soon after fertilization blastodisc (Figure 4C) just formed as a crescentic light area over one end of the massive yolk and the first cleavage (Figure 4D) took place about $35 \mathrm{~min}$ after fertilization which eventually followed by second (Figure 4E), third (Figure $4 \mathrm{~F}$ ), fourth (Figure 4G) and fifth cleavage (Figure 4H) at 45-50 min, 1.00-1.05 h, 1.13-1.18 h, 1.27-1.30 h of post fertilization, respectively. Chakrabarty and Mondal (2008) observed first cleavage of $O$. pabda in about 30 min after fertilization. Rakhi et al. (2015) have similarly found the first cleavage of Nandus nandus eggs at $0.3 \pm 0.01 \mathrm{~h}$ post fertilization at $26^{\circ} \mathrm{C}$ water temperature. According to Zhu et al. (2018), about 54 min after fertilization the first cleavage furrow occurred in top mouth gudgeon, Pseudorasbora parva. However the 64 cell stage (Figure 4I) was observed in $1.30 \mathrm{~h}$ and $O$. pabda took $1.50 \mathrm{~h}$ to complete cleavage stage besides appearing early morula stage (Figure 4J) and late morula stage (Figure 4K). According to Ferosekhan et al. (2015), Pangasius pangasius appeared 64 cell stage and morula stage at $1.27-1.30 \mathrm{~h}$ and $03.43 \pm 00.33 \mathrm{~h}$, respectively. Gastrula stage (Figure 4L) was found in $O$. pabda within 4.50 to $5.00 \mathrm{~h}$ post fertilization. In previous study, researchers reported that $H$. fossilis (Puvaneswari et al., 2009) took $7 \mathrm{~h}$ to reach in gastrula stage. In the current study, yolk plug stage (Figure 4M), kidney bean shaped (Figure 4N) and optical vesicle stage (Figure 4O) were observed after $6 \mathrm{~h}, 8 \mathrm{~h}$ and $12 \mathrm{~h}$ of post fertilization, respectively. Vigorous thrashing movements (Figure 4P) of the embryo were also noticed about 1-2 $\mathrm{h}$ before hatching (Figure 5A) and finally the embryo hatched out (Figure 5B) at $23 \mathrm{~h}$. Similar result has also been reported in case of O. pabo and it took $22 \mathrm{~h}$ for hatching after fertilization (Sarma et al., 2012). Similarly O. bimacuatus hatched out in $21 \pm 1 \mathrm{~h}$ post fertilization (hpf) and yolk-sac completely absorbed in $48 \mathrm{hpf}$ (Raizada et al., 2013). It was also reported that $C$. batrachus (Roy et al., 2019), H. fossilis (Puvaneswari et al., 2009), Mastacembelus aculeatus (Sahoo et al., 2007) and M. cavasius (Rahaman et al., 2004) took 26 h, 23-24 h, 31.45 h and 17 to $21 \mathrm{~h}$, respectively for 
hatching. The hatchlings of $O$. pabda were yellowish black in color and measured 2-3 $\mathrm{mm}$ in length. The lengths of newly hatched hatchlings of M. montanus were also $3.0 \pm 0.1 \mathrm{~mm}$ (Arockiaraj et al., 2003). Observation made on the newly hatched larvae of $H$. fossilis has been recorded with the length of $2.5 \pm 0.2 \mathrm{~mm}$, which was transparent and faintly brown in colour (Puvaneswari et al., 2009). Mukherjee et al. (2002) reported the length 5-6 mm in $O$. pabo, while Rahaman et al. (2004) reported 2.59 to $2.62 \mathrm{~mm}$ in M. cavasius. Marimuthu and Haniffa (2007) revealed that length variation in different species can be related to the size of eggs.

\subsection{Larval development of $O$.pabda}

The larval developmental stages of $O$. pabda are elaborated with key features in Table 4. The newly hatched $O$. pabda larvae were slender and yellowish black in color with 2-3 mm in length whereas Marimuthu and Haniffa (2007) reported transparent and faintly brown Channa striatus hatchlings with $3.4 \pm 0.2 \mathrm{~mm}$ in length. The hatchlings had no pigmented eyes and devoid of distinct mouth and pectoral with a small head attached to the yolk sac (Figure 5B). The $6 \mathrm{~h}$ old larvae (Figure 5C) were transparent with some star shaped dark black brown melanophores on both side of yolk sac and $12 \mathrm{~h}$ old larvae (Figure 5D) body was straight, floating on the surface of water with prominent notochord. Similar results had found in Notopterus notopterus (Srivastava et al., 2012) with deep yellow to dark pink body. After $24 \mathrm{~h}$ of hatching (Figure 5E), O. pabda larvae remained motionless in the water surface with visible lateral line. Swim bladder and nostril were clearly visible after $48 \mathrm{~h}$ (Figure 5F) of hatching. The yolk sac was gradually started to disappear on the $3 \mathrm{~d}$ onwards (Figure 5G). At the end of this stage yolk sac was absorbed to half size, the larvae were found to swim vigorously and feeding exogenously (Figure 5H). Chakraborty et al. (2010) was also observed that the absorption of yolk sac in $O$. pabda from three days. In P. pangasius (Ferosekhan et al., 2015) yolk absorption occurred at day four post-hatch. This period varies in the fish species such as $72 \mathrm{~h}$ for C. batrachus (Sahoo et al., 2004) and 64.0 $\pm 0.30 \mathrm{~h}$ for N. nandus (Rakhi et al., 2015). At $5 \mathrm{~d}$ post hatch (Figure 5H) larvae were observed free swimming with fully developed mouth, caudal fin and pectoral fin and they were capable to catch their feeds. Larvae took 5-10 days for $P$. pangasius (Ferosekhan et al., 2015) and 6 days for H. fossilis (Puvaneswari et al., 2009) to swim freely. The larvae resembled the adult in their external features and were metamorphosed to young juveniles within 20 days of post-hatching.

Table 1. Physicochemical parameters managed during entire experimental period (values are presented with the mean and standard error of samples).

\begin{tabular}{ll}
\hline Physicochemical parameters & Range \\
\hline Temperature $\left({ }^{\circ} \mathrm{C}\right)$ & $26.5 \pm 2.2$ \\
$\mathrm{pH}$ & $7.4 \pm 0.2$ \\
Dissolved oxygen $(\mathrm{mg} / \mathrm{L})$ & $6.7 \pm 0.5$ \\
Alkalinity $(\mathrm{mg} / \mathrm{L})$ & $85 \pm 7.1$ \\
Hardness $(\mathrm{mg} / \mathrm{L})$ & $56 \pm 8.3$ \\
\hline
\end{tabular}

Table 2. Male and female gonadosomatic index (GSI) during the reproductive months of $O$. pabda (values are presented with the mean and standard error of samples).

\begin{tabular}{lll}
\hline Months & Female GSI & Male GSI \\
\hline March & $2.19 \pm 0.30$ & $0.17 \pm 0.02$ \\
April & $3.27 \pm 0.30$ & $0.24 \pm 0.03$ \\
May & $3.83 \pm 0.10$ & $0.53 \pm 0.25$ \\
June & $6.75 \pm 0.20^{*}$ & $1.05 \pm 0.20^{*}$ \\
July & $5.14 \pm 0.20^{*}$ & $0.83 \pm 0.03^{*}$ \\
August & $4.29 \pm 0.18^{*}$ & $0.23 \pm 0.28$ \\
September & $2.30 \pm 0.23$ & $0.14 \pm 0.02$ \\
\hline
\end{tabular}

$*$ Values are significantly different $(\mathrm{P}<0.01)$. 
Table 3. Early embryonic developmental features of $O$. pabda reared at $26-28{ }^{\circ} \mathrm{C}$.

\begin{tabular}{|c|c|c|c|}
\hline $\begin{array}{l}\text { Time after } \\
\text { spawning }\end{array}$ & $\begin{array}{l}\text { Stages of } \\
\text { development }\end{array}$ & Key features & Plate No. \\
\hline $0 \mathrm{~min}$ & Unfertilized eggs & $\begin{array}{l}\text { Eggs were blackish in color, not transparent, not adhesive and } \\
\text { enveloped by a thick blackish chorion. }\end{array}$ & $4 \mathrm{~A}$ \\
\hline $0 \mathrm{~min}$ & Fertilized eggs & Fertilized eggs were brownish in color, adhesive in nature, very & $4 \mathrm{~B}$ \\
\hline $15 \mathrm{~min}$ & $\begin{array}{l}\text { Blastodisc just } \\
\text { formed }\end{array}$ & $\begin{array}{l}\text { transparent and had a reddish brown spot on one side. } \\
\text { Crescentic light area over one end of the massive yolk of } \\
\text { fertilized eggs were formed. }\end{array}$ & $4 \mathrm{C}$ \\
\hline $35 \mathrm{~min}$ & 2 cell stage & First cleavage with formation of blastoderm over one end of yolk. & $4 \mathrm{D}$ \\
\hline $45-50 \min$ & 4 cell stage & Second cleavage & $4 \mathrm{E}$ \\
\hline $1.00-1.05 \mathrm{~h}$ & 8 cell stage & Third cleavage & $4 \mathrm{~F}$ \\
\hline $1.13-1.18 \mathrm{~h}$ & 16 cell stage & Fourth cleavage & 4G \\
\hline $1.27-1.30 \mathrm{~h}$ & 32 cell stage & Fifth cleavage & $4 \mathrm{H}$ \\
\hline $1.50 \mathrm{~h}$ & 64 cell stage & Sixth cleavage & $4 \mathrm{I}$ \\
\hline $1.50-2.00 \mathrm{~h}$ & Early Morula stage & Repeated cleavage resulted into early morula. & $4 \mathrm{~J}$ \\
\hline $3.00 \mathrm{~h}$ & Morula stage & $\begin{array}{l}\text { Blastoderm cells began involution over the yolk and eggs were } \\
\text { with a small perivitelline space. }\end{array}$ & $4 \mathrm{~K}$ \\
\hline $4.50-5.00 \mathrm{~h}$ & Gastrula stage & $\begin{array}{l}\text { The blastoderm covered about } 3 / 4 \text { of the yolk. Gastrulation ring } \\
\text { was formed. }\end{array}$ & $4 \mathrm{~L}$ \\
\hline $6.00 \mathrm{~h}$ & Yolk plug stage & Gastrulation spreads to the whole yolk & $4 \mathrm{M}$ \\
\hline $7.00-8.00 \mathrm{~h}$ & Kidney bean shaped & The head and tail turned into oval shape & $4 \mathrm{~N}$ \\
\hline $12.00 \mathrm{~h}$ & Optic vesicle stage & $\begin{array}{l}\text { The earliest indication of embryo was discernible and embryo } \\
\text { reveals rudimentary optic cubs }\end{array}$ & $4 \mathrm{O}$ \\
\hline $18.00 \mathrm{~h}$ & Twisted movement & $\begin{array}{l}\text { The heart was beating actively. Tubular notochord was appeared } \\
\text { and the embryos showed occasional faint twisting movements }\end{array}$ & $4 \mathrm{P}$ \\
\hline
\end{tabular}

Table 4. Larval developmental features of $O$. pabda reared at $26-28{ }^{\circ} \mathrm{C}$.

\begin{tabular}{|c|c|c|}
\hline Developmental stages & Key features & Plate No. \\
\hline Just before hatching & $\begin{array}{l}\text { Egg membrane became decomposed and lost its shape. Vigorous thrashing } \\
\text { movements and frequent whipping motion of the embryo. }\end{array}$ & $5 \mathrm{~A}$ \\
\hline Newly hatched larvae & $\begin{array}{l}\text { Lack of mouth and pectoral fin, head region was attached to the yolk sphere. } \\
\text { Body was observed without any pigmentation. }\end{array}$ & $5 \mathrm{~B}$ \\
\hline $6 \mathrm{~h}$ old larva & $\begin{array}{l}\text { Some star or branch shaped melanophores distributed on both side of the body } \\
\text { and back of the head and somites. The body of the larva was straight, floating } \\
\text { on the surface of the water. The brain was slightly visible. Prominent } \\
\text { notochord was found and barbell partially appeared. }\end{array}$ & $5 \mathrm{C}$ \\
\hline $12 \mathrm{~h}$ old larva & $\begin{array}{l}\text { Three pair of barbell appeared and among them the maxillary pair was clearly } \\
\text { visible. Heart became more distinct and blood circulation was continued. }\end{array}$ & $5 \mathrm{D}$ \\
\hline 24 h old larva & $\begin{array}{l}\text { Lateral line was visible. Swim bladder and nostril also formed. Larvae still } \\
\text { remained motionless in the surface layer of water. Pigmentation extended to } \\
\text { the yolk sac both dorsally and ventrally }\end{array}$ & $5 \mathrm{E}$ \\
\hline $2 \mathrm{~d}$ old larva & $\begin{array}{l}\text { Typical star-shaped melanophores clusters appear around the final tract of the } \\
\text { intestine. }\end{array}$ & $5 \mathrm{~F}$ \\
\hline $3 \mathrm{~d}$ old larva & $\begin{array}{l}\text { Yolk sac was gradually disappeared and was absorbed to half size. Mouth was } \\
\text { gradually developed and feeding commenced at this stage. }\end{array}$ & $5 \mathrm{G}$ \\
\hline $4 \mathrm{~d}$ old larva & $\begin{array}{l}\text { Tail and caudal fin formation were in progress and } \\
\text { both maxillary and mandibular barbells were formed. }\end{array}$ & $5 \mathrm{H}$ \\
\hline $5 \mathrm{~d}$ old larva & $\begin{array}{l}\text { Mouth was fully developed and functional. Yolk substances were completely } \\
\text { absorbed. The larva was free swimming and fully capable to capture food. }\end{array}$ & $5 \mathrm{I}$ \\
\hline
\end{tabular}




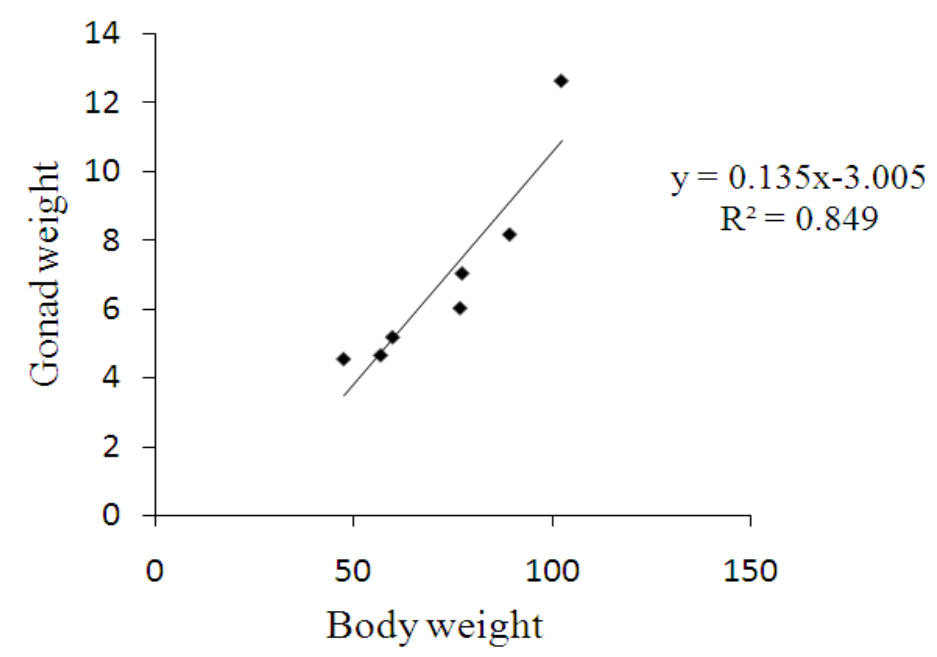

Figure 1. Correlation between body weight and gonad weight of $O$. pabda.

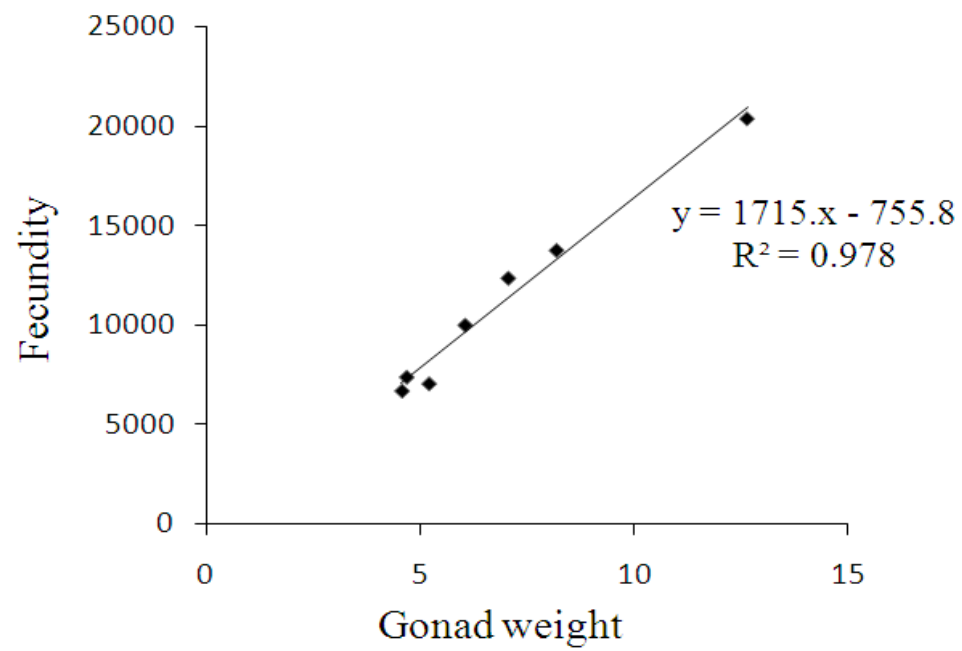

Figure 2. Correlation between fecundity and gonad weight of $O$. pabda.

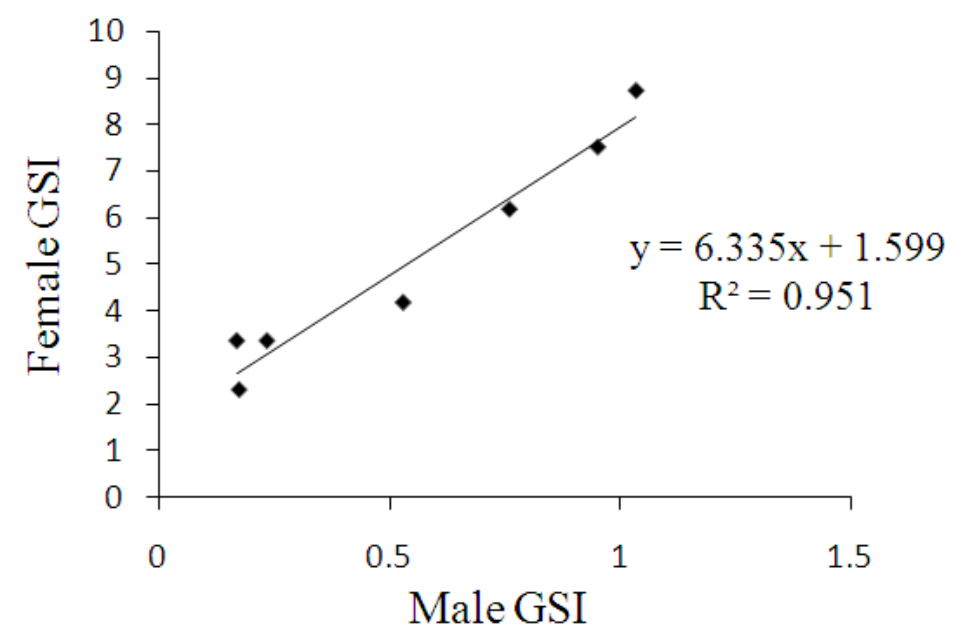

Figure 3. Correlation between male GSI and female GSI of $O$. pabda. 

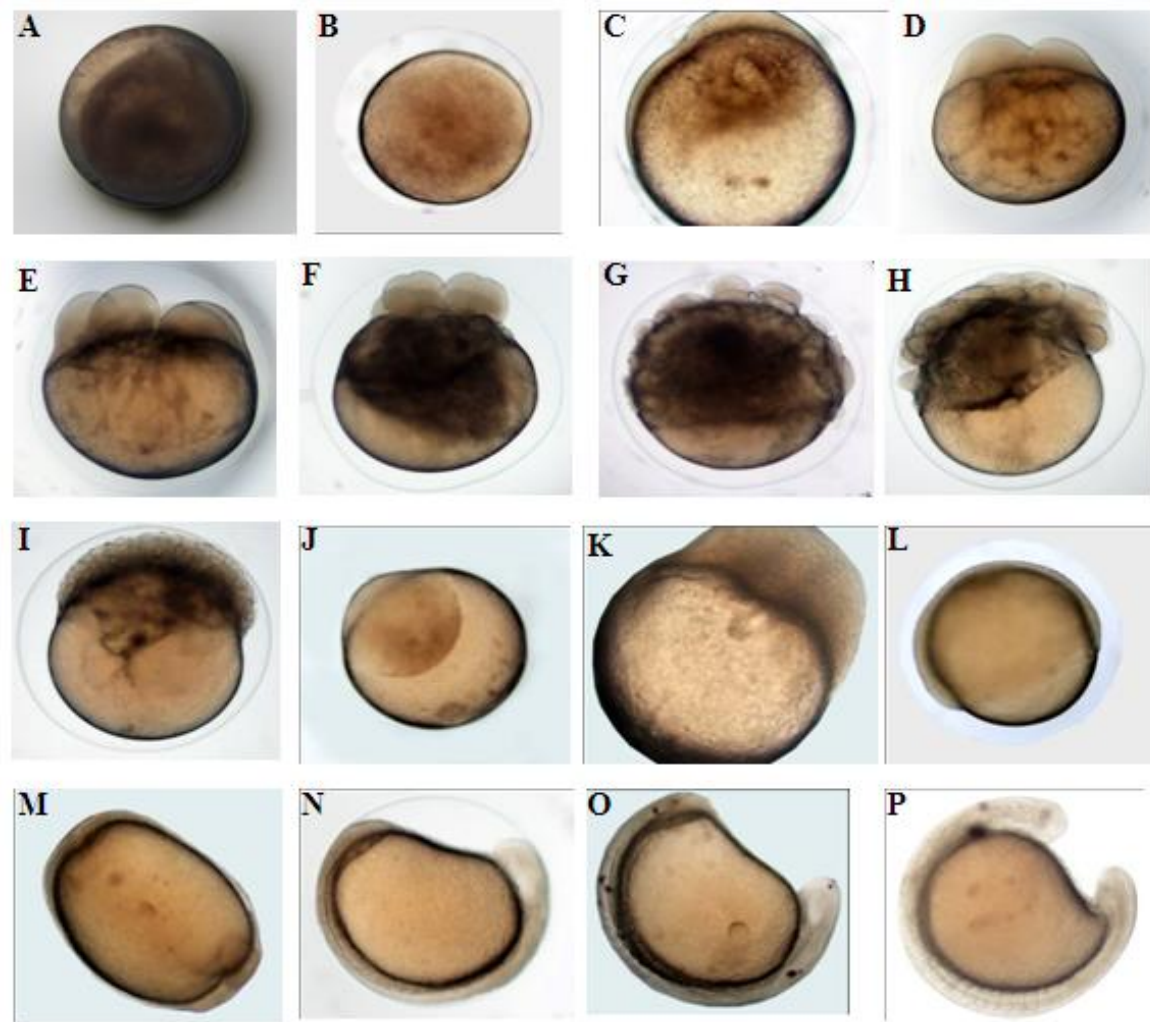

Figure 4. Early embryonic developmental stages of $O$. pabda, A. Unfertilized egg (0 min), B. Fertilized egg, C. Blastodisc just formed $(15 \mathrm{~min})$, D. 2 cell stage $(35 \mathrm{~min})$, E. 4 cell stage $(45-50 \mathrm{~min})$, F. 8 cell stage $(1.00-1.05$ h), G. 16 cell stage $(1.13-1.18$ h), H. 32 cell stage $(1.27-1.30$ h $)$, I. 64 cell stage $(1.50$ h $)$, J. Early morula stage $(1.5 \mathrm{~h}$ to $2.0 \mathrm{~h})$, K. Morula stage $(2.0 \mathrm{~h}$ to $3.0 \mathrm{~h})$, L. Gastrula stage $(4.50 \mathrm{~h}$ to $5.00 \mathrm{~h})$, M. Yolk plug stage $(6 \mathrm{~h}), \mathrm{N}$. Kidney bean shaped $(7 \mathrm{~h}$ to $8 \mathrm{~h})$, $\mathrm{O}$. Optical vesicle stage $(12 \mathrm{~h})$ and $\mathrm{P}$. Twisted movement $(18 \mathrm{~h})$.
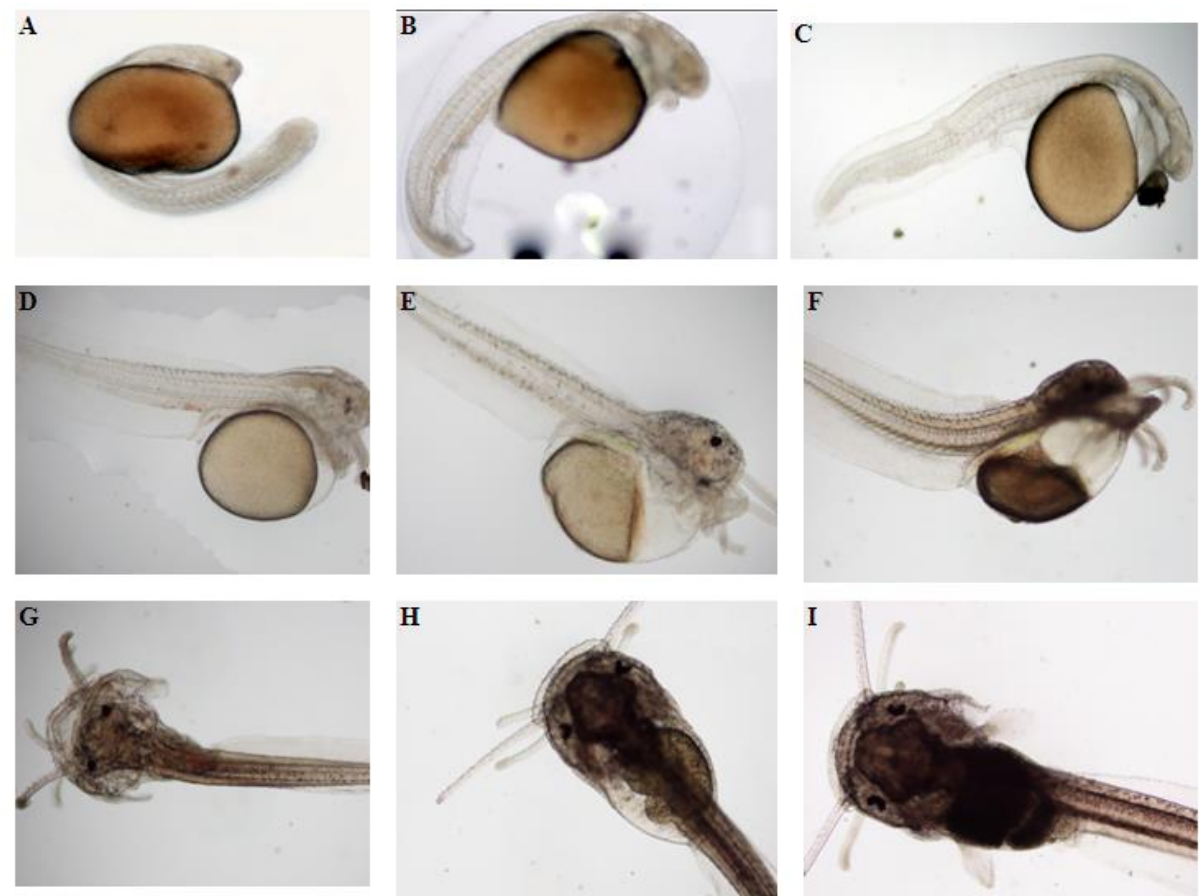

Figure 5. Larval developmental stages of $O$. pabda, A. Just before hatching (23.00 h), B. Newly hatched larva, C. 6 h old larva, D. 12 h old larva, E. 24 h old larva, F. 48 h (2 d) old larva, G. 72 h (3 d) old larva, H. $96 \mathrm{~h}$ (4 d) old larva and I. $120 \mathrm{~h}$ (5 d) old larva. 


\section{Conclusions}

The findings of the present study supplements detailed spawning and developmental biology of $O$. pabda which is now at threat of extinction due to poor breeding and rearing management. This study documents spawning indices along with captive breeding strategy, embryonic and larval development till it completely resembles the adult fish. These findings would be useful for aquaculture entrepreneurs, fish breeders, aquarium keepers and those interested in spawning and developmental study of $O$. pabda to mitigate the probable threats from extinction.

\section{Acknowledgements}

The author remains grateful to extend immense gratitude to the authority of the Krishi Gobeshona Foundation, Bangladesh Agricultural Research Council, Farmgate, Dhaka, Bangladesh for their financial support and cordial cooperation to carry out the present study.

\section{Conflict of interest}

None to declare.

\section{References}

Akhteruzzaman M, AHM Kohinoor, MS Shah and MG Hussain, 1993. Observation on the induced breeding of silurid catfish, Ompok pabda (Hamilton). Bangladesh J. Life. Sci., 5: 71-75.

Arockiaraj AJ, A Mohammed, SS Haniffa and SP Singh, 2003. Early embryonic and larval development of Mystus montanus. Acta Zool. Taiwanica, 14: 23-32.

Banik S, P Goswami, T Acharjee and S Malla, 2012. Ompok pabda (Hamilton-Buchanan, 1822): An endangered Catfish of Tripura, India: reproductive physiology related to freshwater lotic environment. J. Env., 1: 45-55.

Behera S, 2012. Relationship among body weight, gonad weight, fecundity and egg size of an ornamental fighting fish, Betta splendens. J. Biol. Innov., 1: 198-204.

CAMP,1998. Conservation assessment and management plan for freshwater fishes of India. In: Molur S, Walker S (Eds.), Workshop report zoo outreach organization, Coimbator/CBGS and NBFGR, Lucknow, India, pp. 1-158.

Chakrabarti NM, PP Chakraborti, SC Mondal and N Sarangi, 2008. Embryonic development of Pabda (Ompak pabda) with note on its farming. Fish. Chimes., 28: 55-59.

Chakrabarty NM and PP Chakrabarti, 2005. Embryonic development and larval rearing of Ompok pabda (Hamilton). J. Inland Fish. Soc. India, 37: 71-74.

Chakrabarty NM, PP Chakrabarti and SC Mondal, 2006. Mass seed production of pabda and their farming-a challenging step for sustainable utilization of the vulnerable fish species. Fish. Chimes., 26: 133-135.

Chakrabarty NM and SC Mondal, 2008. Observed breeding and seed production of butter catfish, Ompok pabda (Siluridae) at Kalyani Centre of CIFA, India. INFOFISH Int., 6: 19-25.

Chakraborty BK, ZA Mirza and A Chakraborty, 2010. Reproductive cycle of the endangered Pabda, Ompok pabda (Hamilton-Buchanan, 1822) in Bangladesh. Asia. Fish. Sci., 23: 301-320.

Devlaming V, G Grossman and F Chapman, 1982. On the use of the Gonodosomatic Index. Comp. Biochem. Physiol., 73: 31-39.

Ferosekhan S, SK Sahoo, SS Giri, A Saha and M Paramanik, 2015. Embryonic and Larval Development of Yellow Tail Catfish, Pangasius pangasius. J. Aquac. Res. Dev., 6: 6.

Gupta J, 2018. A Review on Feeding and Reproductive Biology of Ompok pabda with an Emphasis on its Conservation. J. Aquac. Res. Dev., 9: 525.

Gupta S and S Banerjee, 2013. Indigenous ornamental fish trade of West Bengal. Narendra Publishing House, New Delhi, India, pp. 63.

Hartman WL and CY Conkle, 1960. Fecundity of red salmon at brooks and karluk Lakes, Alaska. Fish. Bul., 180: 53-60.

Hossain J, MJ Sarker, MN Uddin, A Islam, IJ Tumpa and Z Hossain, 2018. Macrobenthos presence in the estuarine waters of the Meghna river, Ramghati, Laksmipur, Bangladesh. World Appl. Sci. J., 36: 598-604.

Hossen MA, MY Hossain, K Yahya and MNU Pramanik, 2015. Threatened Fishes of the World: Labeo bata (Hamilton, 1822) (Cypriniformes: Cyprinidae). Croat. J. Fish., 113-118.

Hossen MS, AHMM Reza, SF Rakhi, MM Rahman, MA Alam and Z Hossain, 2014a. Observation of embryonic and early larval development of striped gourami, Trichogaster fasciata (Perciformes: Osphronemidae). EurAsia. J. BioSci., 8: 61-70. 
Hossen MS, AHMM Reza, SF Rakhi, K Takahashi and Z Hossain, 2014b. Effects of polyunsaturated fatty acids (PUFAs) on gonadal maturation and spawning of striped gourami, Colisa fasciatus. Int. Aquat. Res., 6: 65.

Hossen MS, AHMM Reza, SF Rakhi, K Takahashi and Z Hossain, 2014c. Effect of phospholipids in broodstock diets on serum calcium level, gamete quality and spawning of threatened Bagrid catfish gulsha, Mystus cavasius. Int. J. Res. Fish. Aquac., 4: 70-76.

Islam A, A Habib, JM Hossain, IJ Tumpa, ATU Haque and Z Hossain, 2018. Effects of stocking density on growth and survival of Thai pangas (Pangasius hypophthalmus Sauvage, 1878) fry in net cages in a commercial fish farm in Noakhali, Bangladesh. Fundam. Appl. Agric., 3: 586-590.

IUCN, 2015. Red List of Bangladesh Volume 5: Freshwater Fishes. IUCN, International Union for Conservation of Nature, Bangladesh Country Office, Dhaka, Bangladesh, pp. xvi+360.

Jahan H, NS Ema, MS Hossain, MA Pervin, R Akter and Z Hossain, 2019. Effects of soybean meal on new muscle generation and growth of silver barb, Barbonymus gonionotus. Int. J. Agril. Env. Biores., 4: 102-110.

Jhingran VG, 2004. Fish and Fisheries of India. Reprinted. Daya Publisher, Delhi.

Malla S and S Banik, 2015. Reproductive biology of an endangered catfish, Ompok bimaculatus (Bloch, 1794) in the lotic water bodies of Tripura, North-East India. Int. J. Fish. Aquat. Stud., 2: 251-260.

Marimuthu K, J Arumugam, D Sandragasan and R Jegathambigai, 2009. Studies on the Fecundity of Native Fish Climbing Perch (Anabas Testudineus, Bloch) in Malaysia. Am.-Eurasia. J. Sustain. Agric., 3: 266-274.

Marimuthu K and MA Haniffa, 2007. Embryonic and Larval Development of the Striped Snakehead Channa striatus. Taiwania, 52: 84-92.

Mollah MFA and MN Sarowar, 2009. Growth performance and survival of larvae of Ompok pabda produced from vitamin E treated female brood fish. Prog. Agric., 20: 125-132.

Mollah MFA and Z Hossain, 1998. Stocking density effects on growth and survival of African catfish (Clarius gariepinus) fry in net cages. Bangladesh J. Agril. Sci., 25: 5-9.

Mollah MFA and Z Hossain, 1995. Growth and survival of African catfish, Clarias gariepinus Burchell fry reared in cages at different stocking densities. Bangladesh J. Zool., 23: 179-182.

Motin MA, MRU Sarkar, M Maya, MJ Alam, ZP Sukhan and H Rashid, 2013. Histological study of gametogenesis in endangered pabo catfish (Ompok pabo) from the Sylhet basin in the north-east Bangladesh. 5th International Conference on Environmental Aspects of Bangladesh, 21: 109-112.

Mukherjee M, A Praharaj and S Das, 2002. Conservation of endangered fish stocks through artificial propagation and larval rearing technique in West Bengal, India. Aquac. Asia Magazine, 7: 8-11.

Mukhopadhyay T and S Ghosh, 2007. Lipid profile and fatty acid composition of two silurid fish eggs. J. Oleo Sci., 56: 399-403.

Purkayastha S, S Sarma, UK Sarkar, WS Lakra, S Gupta and SP Biswas, 2012. Captive Breeding of Endangered Ompok pabda with Ovatide. J. Appl. Aquac., 24: 42-48.

Puvaneswari S, K Marimuthu, R Karuppasamy and MA Haniffa, 2009. Early embryonic and larval development of Indian catfish, Heteropneustes fossilis. EurAsia. J. BioSci., 3: 84-96.

Rahaman MR, MA Rahaman, MN Khan and MG Hussain, 2004. Observation on the embryonic and larval development of Silurid catfish, Gulsha (Mystus cavasius). Pakistan J. Biol. Sci., 7: 1070-1075.

Raizada S, KK Lal, U Sarkar, PK Varshney, V Sahu, KC Yadav, P Agnihotri, A Awasthi and JK Jena, 2013. Captive Breeding and Embryonic Development of Butter Catfish (Ompok bimaculatus, Bloch 1794), a Threatened Fish of Indian Sub-continent in Northern India. Proceedings of the National Academy of Sciences, India Section B: Biol. Sci., 83: 333-339.

Rajagopal B and P Davidar, 2013. Distribution of catfishes in wetlands of two flood plain districts in Tamil Nadu, India. J. Threat. Taxa, 5: 5277-5282.

Rakhi SF, AHMM Reza, MS Hossen and Z Hossain, 2015. Embryonic development and growth performances of an endangered fish species Nandus nandus: effects of dietary polyunsaturated fatty acids supplementation. Iran. J. Fish. Sci., 14: 1029-1052.

Reza AHMM, SF Rakhi, MS Hossen, K Takahashi and Z Hossain, 2013. Enhancement of reproductive performances of Gangetic leaffish, Nandus nandus through up regulation of serum $\mathrm{Ca}^{2+}$ concentration, improved morphological alteration of liver and ovary with dietary polyunsaturated fatty acids. Fish Physiol. Biochem., 39: 779-791.

Roy D, A Mitra, M Biswas, S Chakraborty, S Pal and S Homechaudhuri, 2019. Early ontogeny of the Asian catfish Magur, Clarias batrachus (Linnaeus, 1758). Int. J. Fish. Aquat. Stud., 7: 287-292.

Saha SK, MH Ali and H Rashid, 2014. Gametogenesis in Captive Stinging Catfish (Heteropneustes fossilis) During Spawning Season. Proceedings of 5th International Conference on Environmental Aspects of Bangladesh, 126-128. 
Sahoo SK, SS Giri, A Saha, S Chandra, AK Sahu and N Sarangi, 2007. Embryonic development of the spiny eel, Mastacembelus aculeatus (Bloch, 1786). India J. Fish., 54: 333-337.

Sahoo SK, SS Giri and AK Sahu, 2004. Effect of stocking density on growth and survival of Clarias batrachus (Linn.) larvae and fry during hatchery rearing. J. Appl. Ichthyol., 20: 302-305.

Sarma D, J Das, A Dutta and UC Goswami, 2012. Early embryonic and larval development of Ompok pabo with notes on its nursery rearing. Europe. J. Exp. Biol., 2: 253-260.

Srivastava SM, A Gopalakrishnan, SP Singh and AK Pandey, 2012. Embryonic and larval development of threatened bronze featherback, Notopterus notopterus (Pallas). J. Exp. Zool. India, 15: 425-430.

Vijayakumar C, 2010. Early embryonic and larval development of Ompok malabaricus. Int. J. Biol. Tech., 1: 131-133.

Yusuf K, SA Dada and MA Abari, 2013. Length-Weight relationship, fecundity and gonadal development of the African catfish (Clarias gariepinus) from Doma dam, Nasarawa state, Nigeria. Produc. Agric. Tech., 9: 47-58.

Zadmajid V, SR Sørensen and IAE Butts, 2018. Embryogenesis and early larval development in wild-caught Levantine scraper, Capoeta damascina (Valenciennes, 1842). J. Morph., 280: 133-148.

Zhu D, K Yang, N Sun, W Wang and X Zhou, 2018. Embryonic and larval development of the topmouth gudgeon, Pseudorasbora parva (Teleostei: Cyprinidae). Zoologia, 35: 1-8. 